\title{
Window dressing in Brazilian investment funds
}

\author{
Matheus Ruiz Marques ${ }^{1}$ \\ (D) https://orcid.org/0000-0003-1659-597X \\ Email: matheus.marques@edu.fecap.br \\ Joelson O. Sampaio ${ }^{1,2}$ \\ (D) https://orcid.org/0000-0001-6560-2481 \\ Email: joelson.sampaio@fecap.br \\ Vinicius Augusto Brunassi Silva ${ }^{1}$ \\ (D) https://orcid.org/0000-0002-1299-321X \\ Email: vinicius.brunassi@fecap.br \\ ${ }^{1}$ Fundação Escola de Comércio Álvares Penteado, Departamento de Ciências Contábeis, São Paulo, SP, Brazil
${ }^{2}$ Fundação Getulio Vargas, Escola de Economia de São Paulo, Departamento de Administração, São Paulo, SP, Brazil
}

Received on 08.30.2018 - Desk acceptance on 10.10.2018 - $2^{\text {nd }}$ version approved on 04.12.2019 - Ahead of print on 09.12.2019

Associate Editor: Fernanda Finotti Cordeiro Perobelli

\begin{abstract}
This paper investigates the presence of window dressing in the Brazilian investment fund market, focusing on equity funds. Window dressing is a practice that presents a particular portfolio composition to the market, which is different from that held by the fund in the reporting period. Just before the end of the period, fund managers change their positions with the aim of presenting safer, more profitable securities portfolios. We believe that there is a lack of empirical evidence on this topic in Brazil. Previous research focuses on diversification, style analysis, fund portfolio turnover, manager profile, and performance. Therefore, we believe that our paper is pioneering in presenting results on window dressing in Brazil. With the presence of window dressing, the market may signal distorted results to investors and guide their allocations towards funds in which they would not invest in the absence of such practices. Moreover, the adoption of window dressing may increase transaction costs and thus destroy value. Our results present a connection with previous studies by Bremer and Kato (1996), O'Neal (2001), Ng and Wang (2004), Ortiz, Sarto, and Vicente (2012), and Agarwal, Gay, and Ling (2014). This paper provides evidence of window dressing in Brazilian equity funds and proposes an empirical study to verify the presence of the practice between 2010 and 2016, using market model residuals, rank gap, and backward holding return gap analysis techniques. In short, our results are consistent with window dressing practices in funds managed by small companies that were losers against the Bovespa Index and presented a high tracking error in the period.
\end{abstract}

Keywords: window dressing, stock investment funds, portfolio disclosure, Brazilian market, CVM classification.

Correspondence address

Matheus Ruiz Marques

Fundação Escola de Comércio Álvares Penteado, Departamento de Ciências Contábeis

Avenida Liberdade, 532 - CEP 01502-001

Liberdade - São Paulo - SP - Brazil 


\section{INTRODUCTION}

This paper aims to reveal engagement in window dressing in the Brazilian investment funds market. This practice consists of investment fund managers intervening in order to change a fund's investment positions just before the portfolio is disclosed. By engaging in window dressing, investment fund managers present a securities portfolio composition that does not reflect the reality of the fund in that period. Thus, during the reporting period, managers change their positions in poorly performing equities to better performing ones. The change in portfolio positions aims to present a different portfolio to investors, and this alteration is not driven by the fund's investment strategy.

Holding high quality securities in a portfolio (even when the portfolio did not present consistent overall performance in the period) should not induce investors to allocate funds. However, there is evidence in previous studies indicating that investor decisions in such conditions can be misled. Investors may interpret information incorrectly and take decisions under the influence of noise (Black, 1986). In Brazil, for example, Chague, De-Losso, and Giovannetti (2018) showed that a fall attributed to the stock price (caused by the payment of dividends) is enough for individual investors to buy a security. That is, individuals appear to disregard the information associated with the price of an asset. The studies by Carrillo and Palfrey (2011) and Eyster, Rabin, and Vayanos (2017) corroborate this behavior.

According to Musto (1997), disclosure of the final composition of a portfolio plays an important role in investor decisions. In general, investors are susceptible to holding investments in investment funds that present high performance securities in their portfolios, even when the fund shows poor prior performance (Morey and O'Neal, 2006). This result is a partial reflection of the connection investors make between the portfolio reported to the market and the manager's ability to choose securities (Grinblatt \& Titman, 1989, 1993; Wermers, 2000). It is therefore expected that, in order to raise more funds for their investment funds, managers practice window dressing.

The research on investment funds in Brazil presents results involving fundraising (Sanvicente, 2002), the role of managers (Leusin \& Brito, 2008), style analysis
(Yoshinaga, Castro, Oda \& Lucchesi, 2009), fund portfolio rotation (Milan \& Eid, 2015), diversification (Moraes \& Serra, 2017), and performance (Matos \& Castro, 2013; Trindade \& Malaquias, 2015; Oreng, Eid \& Yoshinaga, 2017). However, we believe that there is a lack of empirical results on the theme proposed for this research in Brazil.

Thus, this paper contributes to the literature by presenting empirical evidence of window dressing practices in the Brazilian market. In addition, the research is warranted by the growth in the fund industry in Brazil in the $21^{\text {st }}$ century, which has reached new levels in terms of the funds' consolidated net equity. Between 2000 and 2017 , the fund industry grew by $350 \%$, from approximately $\mathrm{R} \$ 1$ trillion to $\mathrm{R} \$ 4.5$ trillion (Brazilian Association of Financial and Capital Market Entities - Anbima, 2018). As the Brazilian capital market matures and develops, the contribution of this topic, in the practical and theoretical field, tends to gain even more relevance.

Clarifying the evidence of window dressing practices in the Brazilian context enables the inappropriate interpretations that investors may have regarding an investment fund to be highlighted, as well as the abilities of its managers. When the investor's inflow or outflow decision derives from the returns reported by funds (originating from the quotas) and/or from the securities that funds report in their portfolios, this decision may have been misled by window dressing. With the results presented here and, more importantly, with the methodologies proposed, identifying the patterns for window dressing becomes more tangible and provides more confidence for future investment decisions.

We assess the presence of window dressing practices in Brazil by considering the empirical strategies of O'Neal (2001) and Agarwal et al. (2014). The results presented indicate that funds managed by small companies (henceforth called "small manager") present greater evidence of window dressing practices than those managed by large institutions (henceforth called large manager). In addition, we show that funds that lost against the Bovespa Index (Ibovespa) and that presented a high tracking error in the analysis period are also associated with window dressing practices. 


\section{THEORETICAL FRAMEWORK}

One set of international studies indicates the presence of window dressing practices. Haugen and Lakonishok (1988) found evidence in the U.S. market that window dressing is the main factor explaining the high returns of low performance stocks just after the end of the fiscal year. Just before the close of the fiscal year and the final date considered for reporting the portfolio, low performance stocks were sold and possibly bought after the turn of the year. This movement corroborates the January effect, whose academic approach was introduced by Watchel (1942).

Musto (1997) also showed evidence that window dressing has an influence over abnormal returns at the turn of the fiscal year. The study examined security trading patterns in the U.S. money market in periods close to the turn of the fiscal year, when portfolio compositions in this market are disclosed, and it found evidence consistent with window dressing practices in managers' strategies. The results showed that securities maturing on the day after the close of the fiscal year presented a higher return (compared with those maturing on the last day of the fiscal year). This premium is even greater for assets with a higher risk of default. The author attributed this premium to the "disutility" that managers face at the end of the fiscal year when disclosing riskier securities to investors.

For the U.S. private debt securities market, Maxwell (1998) indicated the factors causing the January effect. The findings showed an abnormal increase in the demand for securities with the best rates at the end of the fiscal year, which corroborated the movement expected in a window dressing strategy. In contrast, Lee, Porter, and Weaver (1998) used fund data from the U.S. market covering 1976 to 1993 with the aim of testing the January effect hypotheses that distinguished window dressing from performance hedging. The authors concluded that the most probable source of the excess return of small companies found in the January effect is performance hedging, and not window dressing.

In addition, Lakonishok, Shleifer, Thaler, and Vishny (1991) studied the presence of window dressing practices in 769 U.S. pension fund managers from 1985 to 1989. The authors presented weak evidence that the managers sold more loser stocks close to disclosure at the end of the calendar year, as well as not finding evidence of an increase in the demand for winner stocks in the period. These conclusions were, therefore, divergent from the movements expected for window dressing practices. However, given the characteristics of pension funds, which are held by institutions, which in turn are expected to have more resources and technical abilities than individual investors, these institutions are expected to be less likely to be deceived by window dressing.

Musto (1999) argued that funds whose clientele are individual investors are more likely to practice window dressing. This result corroborated the findings of Lakonishok et al. (1991) regarding pension funds. This is possibly due to the fact that access to the information and weekly databases of money market funds is too costly for individual investors. Thus, in reporting periods, such funds would hold government bond portfolios instead of private securities, as they are less risky. The findings support the presence of window dressing, since the managers actually reallocate funds into safer assets during reporting periods. According to O'Neal (2001), by sharing this logic funds that present high performance in the period reported also have reasons to practice window dressing. The high performance may somehow have been underpinned by securities that investors would not expect to invest in (riskier securities, for example).

Various authors have studied window dressing practices in the U.S. mutual funds market. Meier and Schaumburg (2004) sought to detect an abnormal trading pattern during the last days of the quarter, especially for funds that had just performed poorly. The results showed a significant interaction between the trades carried out by managers and portfolio disclosure dates. In addition, Edward O'Neal (2001) studied the years from 1995 to 2000 and presented evidence of this practice in the period. Using two different methodologies, daily returns and portfolio composition, Morey and O’Neal (2006) analyzed the period from 1998 to 2001 and found strong evidence of window dressing in mutual funds in the U.S. market. For high quality mutual funds, the authors suggested an abnormal movement from private securities towards safer National Treasury bonds.

$\mathrm{Ng}$ and Wang (2004) revealed that, on average, the U.S. funds analyzed sold their small caps with the worst returns in the last quarter of the fiscal year, reflecting manager behavior associated with window dressing practices. Bremer and Kato (1996) examined the presence of window dressing practices in the Tokyo Stock Exchange. The authors found strong evidence that winner stocks are traded more than loser ones in the reporting month, suggesting the presence of window dressing practices aiming to buy winner stocks and disclose them in the portfolio. 
Ortiz et al. (2012) studied 865 debt investment funds in the period from June of 1999 to December of 2006 in the Spanish market. The analysis period provided a sample of 35,171 monthly portfolios grouped by the authors into (i) short-term funds, whose portfolios presented a duration measure of up to two years and (ii) long-term funds, whose portfolios presented a duration measure of more than two years. The authors found evidence that debt investment fund managers hold less weight in government bonds on disclosure dates. In short, the authors concluded that the investment strategies adopted by the fund managers analyzed are apparently based on the portfolio disclosure calendar.

Empirically studying window dressing practices is difficult due to the lack of precise information on the portfolios held by funds between disclosure periods (O’Neal, 2001). However, if portfolio composition information was available, for example, on a day-to-day basis, window dressing practices would not exist, since investors could not be "deceived" by this strategy.

For the U.S. mutual funds universe, O'Neal (2001) estimated that the costs attributed to window dressing may exceed US\$ 1 billion per year. The presence of window dressing practices causes an excessive increase in costs for investment funds. The costs may be implicit, when investors are manipulated regarding the real nature of the portfolio of their investments, and explicit, in the form of transaction costs, given the increased volume of transactions just before disclosure (O’Neal, 2001).

In light of the studies presented, a similar analysis is important for the Brazilian capital market. Investor decisions between investing, holding, or withdrawing resources from a fund may be misled by window dressing practices, which can lead investors to error. Provided that trades in securities are not inconsistent with investment fund policy, nor go against the rules presented to investors in any way, window dressing practices cannot be considered illegal. However, the discussions in the ethical and moral arena are more extensive and do not form part of the scope of this paper.

With the increased participation of the capital market in Brazilian society, specifically with the evolution of the investment fund industry, window dressing practices may play an important role in investor decision making. To show the evolution of the investment fund industry in the Brazilian market in the $21^{\text {st }}$ century, the graphical representation in Figure 1 is presented.

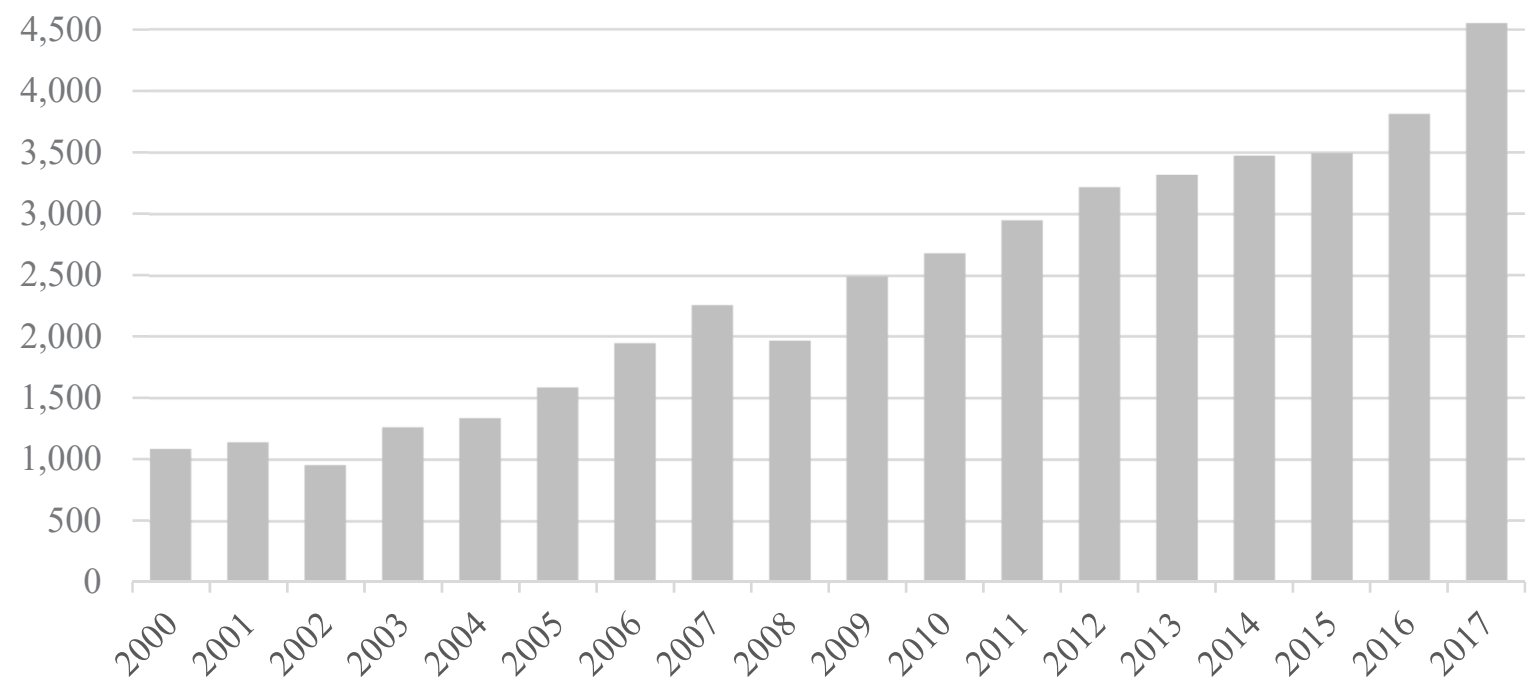

Figure 1 Evolution of the net equity value of the fund industry in Brazil (in billion BRL)

Source: Elaborated by the authors based on data from the Brazilian Association of Financial and Capital Market Entities (Anbima, 2018).

In the 2000s, the fund industry in the Brazilian market presented a net equity of approximately $\mathrm{R} \$$ 1 trillion. In 2017, this position surpassed the R\$ 4.5 trillion mark. Notably, there has been increased participation of investment funds in the Brazilian economic environment and window dressing practices, if implemented, have a maximized potential to penalize market participants. 


\section{DATABASE AND METHODOLOGY}

The sample used for this study is composed of equity investment funds (according to the CVM classification) that have an average net equity between $1 / 1 / 2010$ and $12 / 31 / 2016$ of more than or equal to $\mathrm{R} \$ 1$ million. We adopted this size criterion with the aim of ensuring the funds analyzed were professionally managed, as well as greater availability of data. According to Huang, Sialm, and Zhang (2011), larger funds have fewer problems of absent and incoherent information.

Quota Investment Funds (FICs) were excluded, since funds invested in through FICs, when the criteria are met, already make up the sample of this study.

The funds included in the sample also need to be actively managed. Investment funds with passive management, by definition, seek to achieve returns close to their reference index. There are therefore no reasons for the managers of these funds to seek returns that deviate from the reference index. Actively managed funds, in contrast, seek to beat some reference index and will try to hold (or only disclose) in their portfolios securities that they believe to have this potential.
Given the definitions mentioned in the sample, the Quantum | AXIS database presented 375 funds. Quantum | AXIS is a digital platform that makes it possible to access, analyze, buy, and monitor financial information in a comprehensive database involving funds, stocks, derivatives, managers, registration details, and historical time series data, among others. With 84 months of information, the database presents 31,500 portfolios disclosed to the market.

No other criterion was used to select these 375 funds, including their qualitative characteristics regarding aims or investment policy. Although incentive fees, when used in the form of manager remuneration, may have impacted the funds' ability to choose securities (Elton, Gruber \& Blacke, 2003), this information was also not considered for this study.

To remove possible distortions from the database caused by outliers, 1 percentile of the sample ( 315 portfolios) was eliminated, these being the 157 portfolios with the highest calculated return and the 158 portfolios with the lowest calculated return.

Table 1 presents the descriptive statistics of the portfolios, considering the separation by net equity.

Table 1

Descriptive statistics of the chosen sample (in million BRL)

\begin{tabular}{|c|c|c|c|c|c|c|}
\hline Net equity interval & $\begin{array}{l}\text { Number of } \\
\text { funds }\end{array}$ & $\begin{array}{l}\text { Total number of } \\
\text { portfolios }\end{array}$ & $\begin{array}{c}\text { Number of } \\
\text { portfolios without } \\
\text { outliers }\end{array}$ & $\begin{array}{l}\text { Mean net equity } \\
\text { of the fund }\end{array}$ & $\begin{array}{c}\text { Standard deviation } \\
\text { of the net equity of } \\
\text { the fund }\end{array}$ & $\begin{array}{l}\text { Median net } \\
\text { equity of the fund }\end{array}$ \\
\hline $5,000<x$ & 4 & 336 & 327 & 15,222 & 13,007 & 10,705 \\
\hline $1,000<x \leq 5,000$ & 12 & 1,008 & 1,000 & 1,760 & 755 & 1,489 \\
\hline $500<x \leq 1,000$ & 21 & 1,764 & 1,725 & 673 & 135 & 616 \\
\hline $100<x \leq 500$ & 83 & 6,972 & 6,896 & 227 & 112 & 193 \\
\hline $50<x \leq 100$ & 72 & 6,048 & 6,011 & 71 & 15 & 69 \\
\hline $10<x \leq 50$ & 125 & 10,500 & 10,407 & 25 & 11 & 22 \\
\hline $1 \leq x \leq 10$ & 58 & 4,872 & 4,819 & 5 & 3 & 4 \\
\hline Total & 375 & 31,500 & 31,185 & & & \\
\hline
\end{tabular}

Note: Selected sample distributed based on its average net equity between 1/1/2010 and 12/31/2016 and quantification of the number of portfolios for each category. The sample used in this paper excludes the outlier portfolios and, therefore, contains 31,185 analyzed portfolios.

Source: Elaborated by the authors.

To achieve the objective proposed by this paper, three methodologies were used and are presented below.

\subsection{Residuals Analysis}

The residuals analysis consists of using the ordinary least squares (OLS) method to regress the return reported by the investment funds (represented by the profitability of the securities) with the return calculated based on their portfolio asset composition. The residuals analysis was elaborated based on the market model residuals model used by O'Neal (2001). The smaller the residuals generated by this relationship, the greater the explanatory power of the dependent variable in terms of the fund's 
reported return. From a different perspective, the greater the residuals generated by the relationship presented in the OLS, the stronger the evidence that, on average, the funds that compose the sample practice window dressing. By regressing the funds' reported returns with the calculated returns, we have, in equation 1 :

$$
R E P_{i, t}=a_{i}+C A L C_{i, t}+e_{i, t}
$$

in which $R E P_{\mathrm{i}, \mathrm{t}}$ is the return reported by fund $i$ in period $t, \alpha_{\mathrm{i}}$ is the constant term, $C A L C_{\mathrm{i}, \mathrm{t}}$ is the calculated return for fund $i$ in period $t$, and $e$ is the error term.

According to Chen Hong, Huang, and Kubik (2004), Yan (2008), and Elton, Gruber, and Blake (2012), the size of the fund is an important variable and can have an influence on performance. In addition, Brown, Harlow and Starks (1996), Chevalier and Ellison (1997), Sirri and Tufano (1998), Cremers and Petajisto (2009), and Huang et al. (2011) showed that loser funds have incentives to increase the risk of their portfolios in comparison with winner funds and, even considering the greater risk, they tend to present a lower return. Finally, the studies cited also presented the tracking error of the fund's portfolio as an important variable due to the managers' behavior in light of past successes and failures against the benchmark. Therefore, we separated the sample for this study by following the characteristics mentioned. Thus:

- The size of the managing institution: according to the net equity information for the managing institutions in the fund industry on $12 / 31 / 2016$, the median net equity was $\mathrm{R} \$ 1.103$ billion. Managers with a net equity above the median were considered "large". Managers with a net equity below the median were considered "small".

- Winners and losers: over the 84 months analyzed, each one of the portfolios was compared to the Ibovespa return in its respective month. The funds that managed to equal or beat the Ibovespa in most of the months were categorized as "winners". The funds that did not achieve this target were considered "losers".

- Tracking error: the median tracking error of the sample was $11.67 \%$ during the 84 months studied. The funds that presented a tracking error greater than or equal to the median were categorized as "high TE". The funds that presented a tracking error lower than the median were classified as "low TE".

The categories presented enable different approaches in the methodologies proposed. This allows for more conclusive results regarding the evidence of window dressing practices. The Results and Data Analysis section presents the results for each one of the categories and their combinations, when applicable.

\subsection{Rank Gap}

As window dressing is an unobservable practice, it is necessary to develop proxies that can detect it. Agarwal et al. (2014) presented two methods for measuring window dressing. The first, called rank gap, consists of elaborating three different ranks and capturing the difference between them. As presented in Table 2, the ranks are: (i) a rank elaborated with the investment fund return information [rank of the fund's return (RFR)]; (ii) a rank elaborated with the proportion of winner stocks in each one of the funds [rank of the proportion of winners (RPW)]; and (iii) a rank elaborated with the proportion of loser stocks in each one of the funds [rank of the proportion of losers (RPL)]. On average, winner investment funds are expected to have a portfolio combination with high proportions of winner stocks and low proportions of loser stocks. And similarly, on average, loser investment funds have low proportions of winner stocks and high proportions of loser stocks. The difference between ranks (rank gap) is elaborated for each one of the 84 months analyzed, seeking consistency of the results during the whole period. For the first rank, the RFR, the investment funds were ordered in decreasing order according to the return on their securities. Thus, by separating the rank into percentiles, the fund with the highest return will be represented in the $1^{\text {st }}$ percentile. In contrast, the fund with the lowest return will be represented in the $100^{\text {th }}$ percentile.

The other two ranks, the RPW and RPL, were composed in two stages: (i) for each one of the 84 months of the sample, a rank was composed with the stocks traded on the Brasil, Bolsa, Balcão (B3) exchange and ordered in decreasing order according to their returns for the month. This rank of stocks was separated into quintiles, in order to identify which stocks were winners ( $1^{\text {st }}$ quintile) and which were losers $\left(5^{\text {th }}\right.$ quintile). The use of this attribution for the highest $20 \%$ and lowest $20 \%$ was based on Jegadeesh and Titman (1993); (ii) considering each monthly portfolio, we captured the percentage share in winner stocks and the percentage share in loser stocks for each one of the funds. Using the percentage share in winner stocks, the funds were ordered in decreasing order, thus making up the RPW. Using the percentage share in loser stocks, the funds were ordered in increasing order, thus making up the RPL.

The numbering present in the ranks represents each percentile into which the sample will be organized. Therefore, it is expected that the portfolio(s) present in the first percentile of the fund return rank will also be present in the first percentile of the other two ranks. There is a basis for this prerogative, since portfolios that reported high performance in the reporting period tend 
to have a greater proportion in winner stocks and a lower proportion in loser stocks. Therefore, funds that presented a low return in the period, but that presented a high proportion of winner stocks in the same period, have greater indications of practicing window dressing. Table 2 presents the illustration of the ranks.

Table 2

Illustration of the ranks proposed by the rank gap methodology

\begin{tabular}{|c|c|c|c|c|c|}
\hline \multicolumn{2}{|c|}{ Fund's return rank } & \multicolumn{2}{|c|}{ Proportion of winners rank } & \multicolumn{2}{|c|}{ Proportion of losers rank } \\
\hline 1 & Best return & 1 & Highest proportion & 1 & Lowest proportion \\
\hline 2 & & 2 & & 2 & \\
\hline 3 & & 3 & & 3 & \\
\hline
\end{tabular}

\begin{tabular}{llllll}
\hline 100 & Worst return & 100 & Lowest proportion & 100 & Highest proportion \\
\hline
\end{tabular}

Source: Elaborated by the authors.

With the separation of the ranks into percentiles, it is possible to measure the difference between ranks (rank gap) using the function in equation 2 :

$$
\text { Rank gap }=R F R-\left[\frac{R P W+R P L}{2}\right]
$$

in which RFR is the fund's return rank, RPW is the proportion of winners rank, and RPL is the proportion of losers rank.

For example, a fund with a higher disclosed return will be represented in the $1^{\text {st }}$ percentile of the RFR. Identifying the presence of winner securities in the fund's portfolio in, for example, $99 \%$ of its composition, this will be represented in the $1^{\text {st }} \mathrm{RPW}$ percentile (since the rank is ordered in decreasing order). Naturally, $1 \%$ of the remaining securities are loser securities. Thus, this fund will be represented in the $1^{\text {st }} \mathrm{RPL}$ percentile (since the rank is ordered in increasing order). Based on the example, the rank gap result will be equal to 0 and, therefore, there will be no evidence of window dressing practices for that fund. As an opposite example, for results of this rank gap equation that are higher or lower than 0 , the greater the distance from this target, the stronger the evidence of window dressing will be.

\subsection{Backward Holding Return Gap (BHRG)}

The second model elaborated by Agarwal et al. (2014) was called backward holding return gap. This method aims to compare the return on the fund's real portfolio and the fund's hypothetical return if it held the stocks of the disclosed portfolio over the whole period reported. This method, involving the return on the securities, which represents the return on the real portfolio, does not consider transaction costs or any fees paid to the fund's manager/administrator, since the hypothetical return also does not have this impact. For each one of the 31,185 portfolios present in the sample (total of 31,500 portfolios minus the 315 outlier portfolios), the return was recalculated based on its assets and respective weights in the portfolio. Therefore, 62,370 information points were considered. For each reported return $(31,185)$ there is a corresponding hypothetical portfolio return $(31,185)$. The comparison between the two portfolio groups was made using the Student $t$ test and non-parametric tests, such as the Wilcoxon rank-sum test, to ensure the robustness of the results.

In general, it is worth highlighting that the methods presented here aim to find evidence of window dressing practices. The lack of daily public information makes it impossible to verify these practices empirically. Therefore, there are limitations for this type of study. The buying of winner stocks and selling of loser stocks close to the reporting dates may also be associated with momentum trading, a strategy adopted by managers with the expectation that winner stocks in the present tend to be equally winning in the future. This interpretation is also valid for loser stocks. Giovannetti, Cavalcante, Chague, and Bueno (2016) documented risk factors in the Brazilian market and found that the momentum trading risk factor is significant in this capital market. 


\section{RESULTS AND DATA ANALYSIS}

\subsection{Residuals Analysis}

The analysis tests confirm the prediction that the independent variable CALC (calculated return) has explanatory power in REP (reported return) at a $1 \%$ level of significance ( $p$-value $=0.0000)$. Applying the model for the different categorizations that the study proposes (manager size, fund's return against the Ibovespa, and tracking error), the $\mathrm{p}$-value presented was the same, demonstrating the consistency of the results. However, the different categories and their combinations presented different $\mathrm{R}^{2}$ results. This reveals that funds with certain characteristics explain reported returns not only through calculated returns, but through other unknown independent variables. The lower the model's $\mathrm{R}^{2}$, therefore, the greater the evidence of window dressing practices. This is explained by the fact that window dressing practices in the model is one of the unknown variables. All else remaining constant, the lower the model's $\mathrm{R}^{2}$, the greater the residual and more significant the window dressing variable for explaining reported return, indicated as REP in this study.

Table 3

Main results of the residuals analysis

\begin{tabular}{|c|c|c|c|}
\hline & Portfolios (n) & Adjusted $\mathbf{R}^{2}$ & Residual (1-R $)$ \\
\hline \multicolumn{4}{|l|}{ Total } \\
\hline Large manager & 23,701 & 0.709883 & $0.290117^{*}$ \\
\hline Small manager & 7,484 & 0.598689 & $0.401311 *$ \\
\hline Total & 31,185 & 0.683318 & 0.316682 \\
\hline \multicolumn{4}{|l|}{ Small manager } \\
\hline And winner & 5,763 & 0.678467 & 0.321533 \\
\hline And loser & 1,721 & 0.504548 & 0.495452 \\
\hline Total & 7,484 & & \\
\hline \multicolumn{4}{|l|}{ Small manager, loser } \\
\hline And high tracking error & 1,134 & 0.449245 & $0.550755^{*}$ \\
\hline And low tracking error & 587 & 0.812705 & $0.187295^{*}$ \\
\hline Total & 1,721 & & \\
\hline
\end{tabular}

* = differences in the means of the residuals significant at $1 \%$.

Source: Elaborated by the authors.

With the finding that funds with a small manager have greater evidence of window dressing practices, we sought to understand whether these funds, when facing an adverse result in relation to the Ibovespa, present even more (or less) evidence for window dressing practices. In the small manager category ( 7,484 portfolios), there are differences
The results show that the funds whose managing companies are classified as small (net equity lower than $\mathrm{R} \$ 1.103$ billion) present a residual $\left(1-\mathrm{R}^{2}\right)$ of 0.401311 . This result is significantly different from the $1 \%$ of the residual $\left(1-\mathrm{R}^{2}\right)$ presented by the funds with a manager interpreted as being large. Therefore, all else remaining constant, the deviation of the residuals from one category in relation to the other is due, at least in part, to the variation in the significance of the window dressing variable in the model. Funds with a manager classified as large present a model in which the window dressing variable presents less significance than the model of funds with a manager classified as small. Besides the statistical findings and seeking explanations for these results, it is possible to infer that the greater flexibility that smaller funds have in their investment strategies could be the possible trigger for window dressing practices. In addition, the studies by Chen et al. (2004), Yan (2008), and Elton et al. (2012) reveal that there is a relationship between the size of the fund and its performance, a result that is directly associated with window dressing practices. Table 3 presents the main results. 
the tracking error as one of the subcategories of the sample is important due to the behavior of the managers in relation to past successes and failures against the benchmark. The funds subcategorized as high tracking error consistently have this characteristic over the 84 months analyzed. The residual $\left(1-\mathrm{R}^{2}\right)$ of the funds with a small manager, losers, and with a high tracking error was 0.550755 and presented a significant statistical difference at $1 \%$ in relation to the funds with a small manager, losers, and with a low tracking error. In short, the residuals analysis demonstrates that funds with a small manager and funds with a small manager, losers, and a high tracking error produce a higher level of residuals, which is statistically significant in relation to their comparative peers (funds with a large manager and funds with a small manager, losers, and a low tracking error, respectively). For O’Neal (2001), artificial rebalancing of a portfolio (window dressing) suggests greater residuals produced by the model (market model residuals). This is a reflection of the lower explanatory power of the dependent variable (calculated returns) in relation to the independent variable (reported returns), as detailed in section 3.1. Therefore, it is feasible to conclude that the funds with a small manager and the funds with a small manager, losers, and a high tracking error, due to the distance of their produced residuals in relation to their comparative peers, are more susceptible to window dressing practices. These results can also be explained by the fact that loser funds have incentives to increase the risk of their portfolios in comparison with winner funds and, even considering the greater risk, tend to present a lower return (Brown et al., 1996; Chevalier \& Ellison, 1997; Cremers \& Petajisto, 2009; Huang et al., 2011).

\subsection{Rank Gap}

The rank gap methodology has the particularity of not using, unlike the other two methodologies of this study, any information on returns calculated by the authors. This mitigates the risk of presenting spurious results derived from returns calculated by means of manual intervention and provides greater robustness to the study. The rank gap proposal is to reveal window dressing practices with the information on returns reported by the funds combined with the returns information of the different stocks available in the market that the funds can acquire. Table 4 presents the results of the rank gap for the 375 funds of the sample separated into the categories already presented.
The mean difference between ranks is presented in percentile units and, thus, the greater the deviation from the target (mean rank gap $=0$ ), the greater the evidence of window dressing practices. This statistical relationship was initially proposed by Agarwal et al. (2014). Funds with a large manager have, on average, 0.99 percentile of a difference between their positions in the RFR and the mean between their positions in the RPW and in the RPL. The funds with a small manager presented an even greater mean difference, of 1.14 percentile. Funds with a small manager presented a greater deviation from the target and, therefore, are statistically more susceptible to window dressing practices, thus corroborating the findings of the previous methodology, the residuals analysis. The results found for the rank gap are consistent with Agarwal et al. (2014). The authors reveal that a fund's performance and the ability of its managers are more related with window dressing than with asset selection. Due to the absence of information regarding the managers' abilities, subsample analyses were carried out. The results found reveal that there is a difference in terms of the size of the funds. Small managers are more associated with window dressing practices when compared with large managers.

\section{Table 4}

Results of the rank gap

\begin{tabular}{lc}
\hline & $\begin{array}{c}\text { Mean rank gap } \\
\text { (absolute values) }\end{array}$ \\
\hline Total & 0.48 \\
\hline Large manager & 0.99 \\
\hline Small manager & 1.14 \\
\hline Small manager, winner & 1.89 \\
\hline Small manager, loser & 1.31 \\
\hline $\begin{array}{l}\text { Small manager, loser, and high } \\
\text { tracking error }\end{array}$ & 1.61 \\
\hline $\begin{array}{l}\text { Small manager, loser, and low } \\
\text { tracking error }\end{array}$ & 0.83 \\
\hline
\end{tabular}

Note: Funds with a net equity above the median of the sample for 12/31/2016 ( $R \$ 1.103$ billion) were considered to be large managers, and funds with net equity below this median were considered to be small managers; funds that equaled or beat the Bovespa Index (Ibovespa) return in most of the 84 months analyzed were considered winning managers, while funds below this level were considered losing managers; funds that surpassed the median of $11.67 \%$ presented during the period studied were classified as high tracking error, and funds that did not surpass the median of the period were classified as low tracking error.

Source: Elaborated by the authors. 
Funds with a small manager, subdivided between winners and losers against the Ibovespa, present divergent conclusions in relation to the residuals analysis technique. The mean rank gap of the funds with a small manager and winners shows a greater deviation from the target ( 1.89 percentile). It is concluded that funds with a small manager and winners are more susceptible to window dressing than funds with a small manager and losers. Although it may be an apparently conflicting result with the one found using the residuals analysis methodology, we should highlight that these methods present different approaches. According to Agarwal et al. (2014), the rank gap method is a relative measure, and the others are considered to be absolute measures. In the residuals analysis method, for example, the calculation is carried out based on the difference between the expected return (market model residuals) and actual return.

Finally, the funds with a small manager, losers, and presenting a high tracking error in the period had a more accentuated deviation from the target than funds with a low tracking error. For these subcategories, the results converge with the findings in the residuals analysis.

As already discussed in the Residuals Analysis subsection, we believe that the greater flexibility attributed to the funds with a small manager regarding movements of their securities may be an indicator that favors window dressing practices. For the funds with a small manager, losers, and presenting a high tracking error, the results also favor window dressing practices. The distance from the target (rank gap $=0$ ) was approximately double the result presented by low tracking error funds.

\section{BACKWARD HOLDING RETURN GAP (BHRG)}

The 31,185 portfolios reported by the investment funds that make up the sample (31,500 total portfolios minus 315 portfolios considered outliers) had their returns recalculated based on the reported portfolio (hypothetical portfolio). These returns, in turn, had their means compared to the reported mean returns of each fund in each one of the months. The methodology uses the premise that the portfolio reported by the fund at the end of each month should represent, at least substantially, the portfolio held during the course of the month (and which was responsible for the return reported by the fund). When calculating the return on the hypothetical portfolio and comparing it with the fund's reported return, seeking a minimum deviation, the premise is necessary. Table 5 presents the main results for the BHRG.

The Student $t$ test was used to test the difference between the means of the returns reported (quotas) by the funds and the calculated returns of the hypothetical portfolio. The categories that presented statistically equal means for both returns were: (i) funds with a small manager, winners; and (ii) funds with a small manager, losers, and a low tracking error.

This result shows that the funds with these characteristics do not present evidence of window dressing practices, since the return on the reported portfolio (hypothetical portfolio) matches the reported return (quotas). In contrast, the other subcategories used in the study - (i) funds with a large manager, (ii) funds with a small manager, (iii) funds with a small manager, losers, and (iv) funds with a small manager, losers, with a high tracking error - presented statistically different means at a $1 \%$ level of significance. Based on this methodology, these funds intuitively present evidence of window dressing. This intuition is based on the decision of the portfolio manager who, when observing winner and loser securities in the reporting period, leans towards winner securities to give the false impression of a greater selection ability (Agarwal et al. 2014). 
Table 5

Main results of the backward holding return gap

\begin{tabular}{lccc}
\hline & \multicolumn{3}{c}{ Mean returns } \\
\hline & Hypothetical portfolio & Reported (quotas) & Student $\boldsymbol{t}(\boldsymbol{t}$-statistic) \\
\hline Total & 0.00460 & 0.00317 & $3.03758^{*}$ \\
\hline Large manager & 0.00458 & 0.00327 & $2.39664^{* *}$ \\
\hline Small manager & 0.00467 & 0.00284 & $1.95215^{* *}$ \\
\hline Small manager, winner & 0.00499 & 0.00477 & 0.23496 \\
\hline Small manager, loser & 0.00359 & -0.00364 & $2.79339^{*}$ \\
\hline $\begin{array}{l}\text { Small manager, loser, and high } \\
\text { tracking error }\end{array}$ & 0.00538 & -0.00457 & $2.80958^{*}$ \\
\hline $\begin{array}{l}\text { Small manager, loser, and low } \\
\text { tracking error }\end{array}$ & 0.00012 & -0.00183 & 0.59876 \\
\hline
\end{tabular}

Note: Funds with a net equity above the median of the sample for 12/31/2016 (R\$1.103 billion) were considered to be large managers, and funds with a net equity below this median were considered to be small managers; funds that equaled or beat the Bovespa Index (Ibovespa) return in most of the 84 months analyzed were considered winning managers, while funds below this level were considered losing managers; funds that surpassed the median of $11.67 \%$ presented during the period studied were classified as high tracking error, and funds that did not surpass the median of the period were classified as low tracking error. * = mean returns different at a 1\% level of significance; ${ }^{* *}=$ mean returns different at a $10 \%$ level of significance.

Source: Elaborated by the authors.

The results of this research corroborate the findings of Bremer and Kato (1996), O'Neal (2001), Ng and Wang (2004), and Ortiz et al. (2012) for the Brazilian market. In addition, the separation presented for size, history of returns, and tracking error was shown to be relevant for Brazil, according to the studies by Brown et al. (1996), Chevalier and Ellison (1997), Sirri and Tufano (1998), Cremers and Petajisto (2009), and Huang et al. (2011) for other markets.

\section{CONCLUSION}

The general conclusions of this research indicate the presence of window dressing practices, especially for funds classified as small, losers, and with a high tracking error. The results presented by the three methodologies tested consistently indicate that funds managed by small companies present greater evidence of window dressing practices than funds managed by large institutions (large manager).

This result may be linked to the greater flexibility that funds managed by smaller companies have regarding their investment strategies. The funds categorized as small manager and that were losers against the Ibovespa during most of the 84 months analyzed presented, in the residuals analysis and in the BHRG, greater evidence of window dressing practices than those funds with a small manager and that were winners in relation to the Ibovespa.

Funds classified as small manager before the adverse results in the reporting period tend to alter their portfolio positions to present different securities to the market
It is important to highlight that the fundamental premise for this methodology is limited. Considering that the reported portfolio will represent the portfolio held during the whole month reported (at least substantially) may be a little optimistic. However, the tests show results that are quite coherent with the other methodologies presented, which provides confidence for adopting the premise. from those causing the adverse results. Finally, the funds with a small manager, losers, and that presented a high tracking error in most of the 84 months consistently showed greater evidence of window dressing practices in the three methodologies. This is the result of greater portfolio movements, including just before reporting, and the greater assumption of risk by the managers given the greater distance from the benchmark. As window dressing cannot be clearly identified empirically, this paper seeks to provide evidence that this practice also occurs in the Brazilian capital market in stock investment funds.

In summary, the methodologies are approximations that are made possible by the level of details that the funds provide in the Brazilian market. As approximations are concerned, the methodologies have limitations. As the fund industry in the Brazilian market has a greater volume of net equity for fixed income and multimarket funds, these funds could serve as a suggestion for future window dressing studies. 


\section{REFERENCES}

Agarwal, V., Gay, G. D., \& Ling, L. (2014). Window dressing in mutual funds. The Review of Financial Studies, 27(11), 31333170.

Associação Brasileira das Entidades dos Mercados Financeiro e de Capitais. (2018). Indústria de fundos alcança $\mathrm{R} \$ 4,5$ trilhões de patrimônio líquido. Retrieved from http://www.anbima. com.br/pt_br/noticias/industria-de-fundos-alcanca-r-4-5trilhoes-de-patrimonio-liquido.htm.

Black, F. (1986). Noise. The Journal of Finance, 41(3), 528-543.

Bremer, M., \& Kato, K. (1996). Trading volume for winners and losers on the Tokyo Stock Exchange. Journal of Financial and Quantitative Analysis, 31(1), 127-142.

Brown, K. C, Harlow, W. V., \& Starks, L. T. (1996). Of tournaments and temptations: An analysis of managerial incentives in the mutual fund industry. The Journal of Finance, 51(1), 85-110.

Carrillo, J. D., \& Palfrey, T. R. (2011). No trade. Games and Economic Behavior, 71(1), 66-87.

Chague, F., De-Losso, R., \& Giovannetti, B. C. (2018). Individuals neglect the informational role of prices: Evidence from the stock market [Working Paper]. Fundação Getúlio Vargas. Retrieved from http://bibliotecadigital.fgv.br/dspace/bitstream/handle/10438/20182/TD\%20467_CEQEF\%2045.pdf;jsession$\mathrm{id}=\mathrm{D} 437 \mathrm{EF} 2 \mathrm{~F} 895 \mathrm{FAD} 1 \mathrm{~F} 39 \mathrm{BB} 52$ C07EECC074? sequence $=4$.

Chen, J., Hong, H., Huang, M., \& Kubik, J. (2004). Does fund size erode mutual fund performance? The role of liquidity and organization. American Economic Review, 94(5), 1276-1302.

Chevalier, J., \& Ellison, G. (1997). Risk taking by mutual funds as a response to incentives. Journal of Political Economy, 105(6), 1167-1200.

Cremers, K. J. M., \& Petajisto, A. (2009). How active is your fund manager? A new measure that predicts performance. The Review of Financial Studies, 22(9), 3329-3365.

Elton, E. J., Gruber, M. J., \& Blake, C. R. (2003). Incentive fees and mutual funds. The Journal of Finance, 58(2), 779-804.

Elton, E. J., Martin, J. G., \& Christopher, R. B. (2012). Does mutual fund size matter? The relationship between size and performance. Review of Asset Pricing Studies 2(1), 31-55.

Eyster, E., Rabin, M., \& Vayanos, D. (2017). Financial markets where traders neglect the informational content of prices. Retrieved from https://ssrn.com/abstract=3117986.

Giovannetti, B. C., Cavalcante, E., Filho, Chague, F. D., \& Silveira Bueno, R. D. L. da (2016). Risk premia estimation in Brazil: Wait until 2041 [Working Paper]. Faculdade de Economia e Administração, Universidade de São Paulo.

Grinblatt, M., \& Titman, S. (1989). Mutual fund performance: An analysis of quarterly portfolio holdings. Journal of Business, 62(3), 393-416.

Grinblatt, M., \& Titman, S. (1993). Performance measurement without benchmarks: An examination of mutual fund returns. Journal of Business, 66(1)47-68.
Haugen, R. A., \& Lakonishok, J. (1988). The incredible January effect: The stock market's unsolved mystery. Nova York, NY: Dow Jones-Irwin.

Huang, J., Sialm, C., S., \& Zhang, H. (2011). Risk shifting and mutual fund performance. The Review of Financial Studies, 24(8), 2575-2616.

Jegadeesh, N., \& Titman, S. (1993). Returns to buying winners and selling losers: Implications for stock market efficiency. The Journal of Finance, 48(1), 65-91.

Lakonishok, J., Shleifer, A., Thaler, R., \& Vishny, R. (1991). Window dressing by pension fund managers [Working Paper]. National Bureau of Economic Research.

Lee, C. F., Porter, D. C., \& Weaver, D. G. (1998). Indirect tests of the Haugen-Lakonishok small-firm/January effect hypotheses: Window dressing versus performance hedging. Financial Review, 33(2), 177-194.

Leusin, L. M. C., \& Brito, R. D. (2008). Market timing e avaliação de desempenho dos fundos brasileiros. RAE - Revista de Administração de Empresas, 48(2), 22-36.

Matos, P. R. F., \& Castro, A. E. N. (2013). Fundos de investimento em ações no Brasil: Performance e expertise de gestão. $B B R-$ Brazilian Business Review, 10(3), 1-38.

Maxwell, W. F. (1998). The January effect in the corporate bond market: A systematic examination. Financial Management, 27(2), 18-30.

Meier, I., \& Schaumburg, E. (2004). Do funds window dress? Evidence for US equity mutual funds. Retrieved from http:// neumann.hec.ca/pages/iwan.meier/window050106.pdf.

Milan, P. L. A. B., \& Eid, W., Junior. (2015). Determinantes da rotatividade das carteiras dos fundos de investimento em ações. BBR - Brazilian Business Review, 12(5), 1-16.

Moraes, A. V, \& Serra, R. G. (2017). Diversificação dos fundos de investimento imobiliário brasileiros. Base, 14(1), p.63-73.

Morey, M. R., \& O’Neal, E. S. (2006). Window dressing in bond mutual funds. Journal of Financial Research, 29(3), 325-347.

Musto, D. K. (1997). Portfolio disclosures and year-end price shifts. The Journal of Finance, 52(4), 1563-1588.

Musto, D. K. (1999). Investment decisions depend on portfolio disclosures. The Journal of Finance, 54(3), 935-952.

$\mathrm{Ng}$, L., \& Wang, Q. (2004). Institutional trading and the turn-ofthe-year effect. Journal of Financial Economics, 74(2), 343-366.

O’Neal, E. S. (2001). Window dressing and equity mutual funds [Working Paper]. Wake Forest University.

Oreng, M. A. C, Eid, W., Junior, \& Yoshinaga, C. E. (2017). Performance de fundos de renda fixa no brasil: Market timing e análise de estilo. Revista de Gestão, Finanças e Contabilidade, 7(3), 314-325.

Ortiz, C., Sarto, J. L., \& Vicente, L. (2012). Portfolios in disguise? Window dressing in bond fund holdings. Journal of Banking \& Finance, 36(2), 418-427. 
Sanvicente, A. Z. (2002). Captação de recursos por fundos de investimento e mercado de ações. RAE - Revista de Administração de Empresas, 42(3), 92-100.

Sirri, E. R., \& Tufano, P. (1998). Costly search and mutual fund flows. The Journal of Finance, 53(5), 1589-1622.

Trindade, J. A. S., \& Malaquias, R. F. (2015). Análise de desempenho de fundos de investimento de renda fixa e renda variável. Revista de Auditoria, Governança e Contabilidade, 3(5), 76-92.

Wachtel, S. B. (1942). Certain observations on seasonal movements in stock prices. The Journal of Business of the University of Chicago, 15(2), 184-193.
Wermers, R. (2000). Mutual fund performance: An empirical decomposition into stock-picking talent, style, transactions costs, and expenses. The Journal of Finance, 55(4), 16551695.

Yan, X. (2008). Liquidity, investment style, and the relation between fund size and fund performance. Journal of Financial and Quantitative Analysis, 43(3), 741-767.

Yoshinaga, C. E., Castro, F. H. F., Junior, Oda, A. L., \& Lucchesi, E. P. (2009). Análise de estilo em fundos multimercados com e sem alavancagem no Brasil. REGES - Revista de Gestão Eletrônica, 2(1), 9-21. 